\title{
The faded stripes of Bengal: a historical perspective on the easternmost distribution of the striped hyena
}

\author{
Muntasir Akash ${ }^{1}$ (D) - Arjun Dheer ${ }^{2}$ (D) . Stephanie M. Dloniak ${ }^{3}$ (D) Andrew P. Jacobson ${ }^{4}$ (D)
}

Received: 23 June 2021 / Revised: 11 November 2021 / Accepted: 15 November 2021 / Published online: 26 November 2021

(c) The Author(s) 2021

\begin{abstract}
The striped hyena (Hyaena hyaena) is an understudied large carnivore with no known historic range map. Knowledge of the past and present extent of its easternmost distribution beyond $85^{\circ}$ east longitude is dubious. Through a comprehensive review of historical evidence and contemporary records, we investigated striped hyena presence in Bengal, i.e., Bangladesh and the Indian state of West Bengal in South Asia. We found 14 historical records, with the oldest one dating to 1876. Our review establishes Bangladesh as a former striped hyena range country and the striped hyena as one of the first large carnivores to go extinct in Bangladesh. We identified northern Bangladesh as part of its historical range (until 1965), and southcentral Bangladesh as a possible part of its historical range. In West Bengal, India, hyenas were historically present up to the southern tributaries of the Brahmaputra River, but the present range is reduced. The area south of the Damodar River is its last refuge in Bengal. We also found 15 contemporary records (2010-2021) in Bengal, from sites situated on the eastern limit of the Chota Nagpur Plateau. These records noted 25 sightings including 9 deaths due to poaching, train accidents, and retaliatory killings. Our review demonstrates that hyenas are currently present up to $87^{\circ}$ east longitude, which extends the currently documented easternmost range for the species by almost 1,000 km. We recommend methods which can be applied to delineate the historical extent of striped hyenas elsewhere as well as for other poorly understood species.
\end{abstract}

Keywords Bangladesh $\cdot$ Carnivore $\cdot$ Extinction $\cdot$ Hyaena hyaena $\cdot$ India $\cdot$ Status

\section{Introduction}

The striped hyena (Hyaena hyaena), one of the four extant hyena species, is native to 41 countries across North and East Africa, the Middle East, the Caucasus, and Central and South Asia (AbiSaid and Dloniak 2015; Castelló 2020). Despite being widespread across two continents, it is classified as Near Threatened by the IUCN Red List with a declining population of fewer than 10,000 mature individuals, occurring patchily and at low densities throughout

Arjun Dheer

arjdheer@gmail.com

1 Department of Zoology, Faculty of Biological Sciences, University of Dhaka, Dhaka 1000, Bangladesh

2 Department of Evolutionary Ecology, Leibniz Institute for Zoo and Wildlife Research, 10315 Berlin, Germany

3 Department of Integrative Biology, Michigan State University, East Lansing, MI 45524, USA

4 Department of Environment and Sustainability, Catawba College, Salisbury, NC 28144, USA its range (Mills and Hofer 1998; Wagner 2006; AbiSaid and Dloniak 2015). Furthermore, it is an understudied member of the family Hyaenidae (Watts and Holekamp 2007). Many aspects of striped hyena behavioral ecology are yet to be understood (Tichon et al. 2020), though its distribution in multiple range countries has been updated recently (Tichon et al. 2016; Derouiche et al. 2020; Bhandari et al. 2020).

The IUCN Status Survey and Conservation Action Plan: Hyaenas (Mills and Hofer 1998) was the first comprehensive effort to gather data on the global distribution of all extant hyena species. The ensuing range maps were drawn by the IUCN Red List mapping unit using the best available methods at the time. Since then, the striped hyena range map has been left unchanged and has not accounted for the far, forgotten reaches of the species' potential distribution. For example, in the most recent IUCN Red List assessment for the species (AbiSaid and Dloniak 2015) - which kept the original 1998 Red List map - the presence of the striped hyena beyond $85^{\circ}$ east longitude was not mentioned. In contrast, Menon (2014) considered its extant range up to $87^{\circ}$ 
east longitude, which geopolitically falls within the state of West Bengal, India. Recent efforts by the Zoological Survey of India (Nandi 2021) corroborated the description given by Menon (2014). More surprisingly, the historical presence of the species is accounted for even farther eastward. IUCN Bangladesh (2015), Khan (2015), Khan (2018), and Castelló (2020) stated that the striped hyena is extinct in Bangladesh, which lies about $1000 \mathrm{~km}$ eastward of the striped hyena distribution from Mills and Hofer (1998) and AbiSaid and Dloniak (2015). Due to the lack of any scientific work discussing hyena occurrence in Bangladesh, the country was not included in the past species status assessments (Mills and Hofer 1998; AbiSaid and Dloniak 2015). However, why, how, or when the striped hyena went extinct from Bangladesh, where it occurred within the country, or whether the species occurred there at all has not been discussed anywhere in the published scientific literature.

Here, we investigated the past and present distribution of striped hyenas in Bengal, a collective regional denomination that includes almost all of Bangladesh and the state of West Bengal, India (Sengupta 2011). By following a structured methodology, we provided empirical evidence to sketch out the pattern of striped hyena historical presence in Bengal. We also accumulated geo-referenced occurrence events in the region between 2010 and 2021 and quantified the amount of loss in the striped hyena range. We discuss the potential of historical distribution records to detect local extinctions and identify range extensions. We also highlight the importance of using historical, verifiable local records to augment range maps and discuss how such findings may inform conservation strategies for hyenas and other species.

\section{Methods}

\section{Delineation of Bengal}

Until the first quarter of the twentieth century, the presentday Indian states of Bihar, Jharkhand, Odisha, and West Bengal, along with most of present-day Bangladesh, were included under the definition of Bengal (Sengupta 2011; Fig. 1). Today, the area lying between 20.5 and $27.9^{\circ}$ north latitude and $86.35^{\circ}$ and $92.30^{\circ}$ east longitude defines the region of Bengal, i.e., present-day West Bengal and part of Bangladesh (Figs. 1 and 2). This delineation, considering part of India and part of Bangladesh, comes with three salient traits: (i) the Bangla language - from which the name has been derived - evolved here, (ii) the region still contains the main nucleus of the Bangla-speaking population, and (iii) the region is situated on the Ganges Delta, the rich alluvial plain formed by some of the largest river tributaries on Earth (Sengupta 2011). To discuss the historical or current presence of hyenas in Bengal, we considered firstlevel administrative units, or divisions, in both West Bengal and Bangladesh (Supplementary Fig. 1). Most of these units were defined in the 1800 s, corroborate contemporary boundaries, and make it easier to trace and compare with historical regions.

The river systems divide Bengal into separate zones as described in Sengupta (2011) (Fig. 1). We followed this scheme and considered five zones based on the river courses. Zone 1, between the north of the Ganges River and the west of the Brahmaputra River, includes the Barind Tract consisting of the Rajshahi and the Rangpur divisions of Bangladesh (Figs. 1 and 2). Zone 1 also extends further north into the Jalpaiguri division, and westward into the Malda division of West Bengal, with a rise in elevation (Figs. 1 and 2). On the west and the south-west of the Hooghly River, the main southern branch of the Ganges River, Zone 2 includes the Bardhaman and the Midnapore divisions of West Bengal (Figs. 1 and 2). In Zone 3 lies Central Bengal, which comprises the Presidency division of West Bengal, and the Khulna, the Barisal, and most of the Dhaka division of Bangladesh (Sengupta 2011; Figs. 1 and 2). This area is bounded by the Hooghly River to the west, the Ganges River to the north, and the Meghna River to the east (Fig. 1). Central Bengal is the most heavily populated part of Bengal (RGCC 2011; BBS 2011). Between the northeast of the Brahmaputra River and the Ganges River, Zone 4 of Bengal accounts for all of north and northeastern Bangladesh, delimited by the Khasi and the Jaintia Hills (Fig. 1). In the southeast, Zone 5 contains southeastern Bangladesh, delimited by the Chattogram Hill Tracts (Sengupta 2011; Fig. 1).

\section{Search protocol}

We adopted the approach of Pullin and Stewart (2006) to construct our literature search protocol. Based on Jacobson et al. (2016), Lozano et al. (2019), and Akash et al. (2021a), preset keywords were chosen. "Scientific or common name of the species," i.e., "hyena" or "striped hyena" or "Indian hyena" or "Hyaena hyaena" AND "region name," i.e., "Bangladesh" or "West Bengal" or "Bengal" were included in combination in every search carried out in three search engines (Google, Archive.org, and Google Scholar). For "common name of the species," we also applied the British variant of the spelling, i.e., "hyaena." We considered both English and Bangla language literature. In the case of the latter, we applied our keyword string, i.e., "common name of the species" AND "region name" in Bangla. We also searched for anecdotes written about game animals with the preset search protocols.

\section{Consideration of literature and timeline}

We classified three clusters of literature: (i) peer-reviewed scientific studies and books/book chapters, (ii) gray literature 


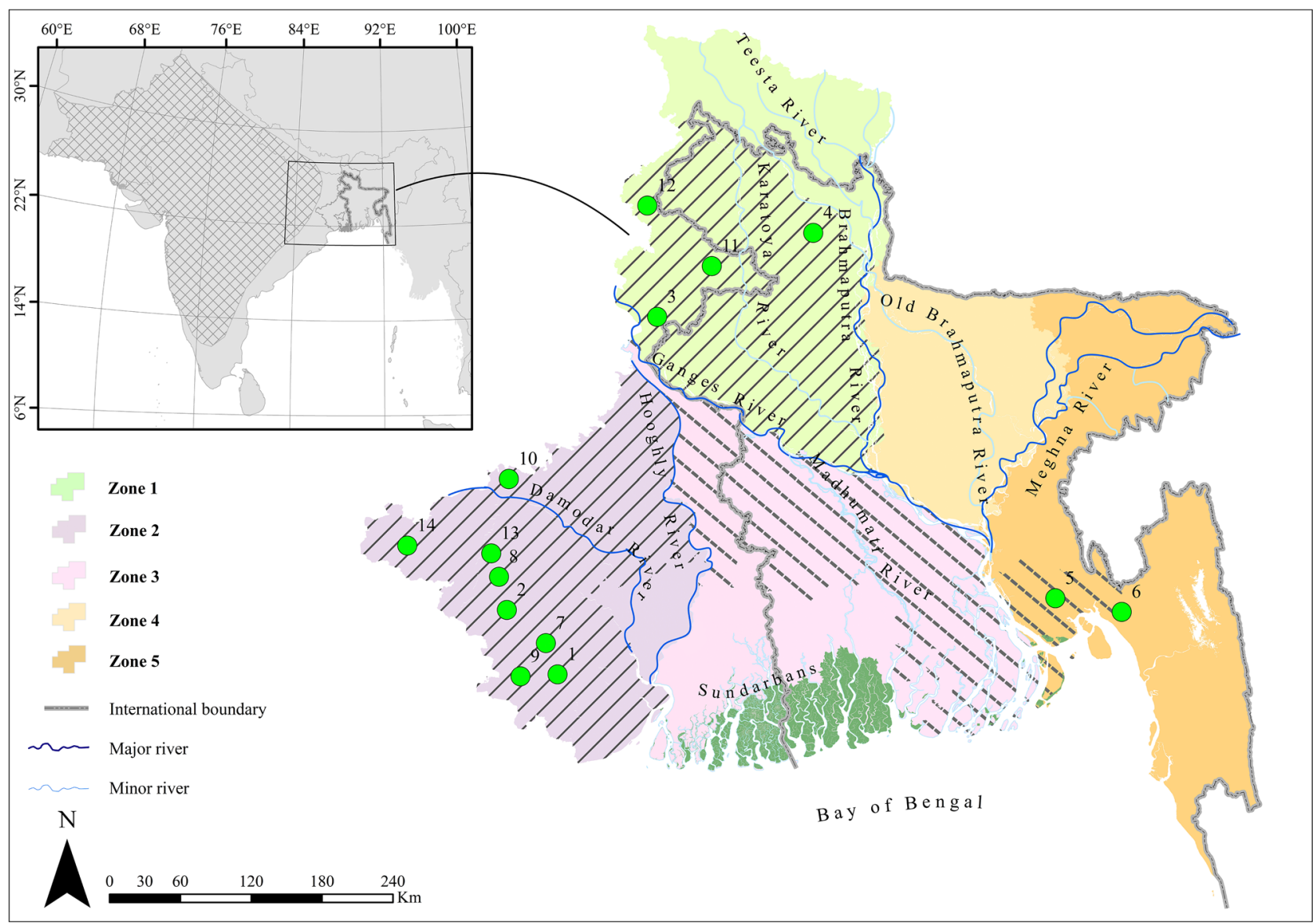

Fig. 1 Historical evidence on the presence of the striped hyena in Bengal. Geographic position of Bengal in the Indian Subcontinent is shown in the inset. Black cross-hatched area denotes the current hyena range in the Indian Subcontinent (from AbiSaid and Dloniak
2015). Green circles denote the historical hyena sighting locations. Numbers beside the circles are site codes and correspond to the observational briefs given in Table 1

news portals (Supplementary Fig. 1). We did not find any media source from Bangladesh as the striped hyena has been extinct there for decades. The sources were chosen based on the highest circulation rates (Hary 2021). In secondary data skimming, readership can be a trait of selection (Akash et al. 2021a; Athreya et al. 2015).

For the third cluster, historical evidence of the striped hyena in the region, we sought out several series of gazetteers: (i) A Statistical Account of Bengal (comprised 20 volumes; compiled by Sir William Wilson Hunter between 1869 and 1877), (ii) The Imperial Gazetteer of India (a 26-volume gazetteer of the then British Indian Empire; published between 1881 and 1887, revised editions until the 1930s), (iii) Bengal District Gazetteers (came out in multiple volumes; each described the then administrative units which represent the present-day divisions; published until the first quarter of the twentieth century), (iv) West Bengal District Gazetteer (a state-wide initiative by the Government of India to update the previous gazetteers; 


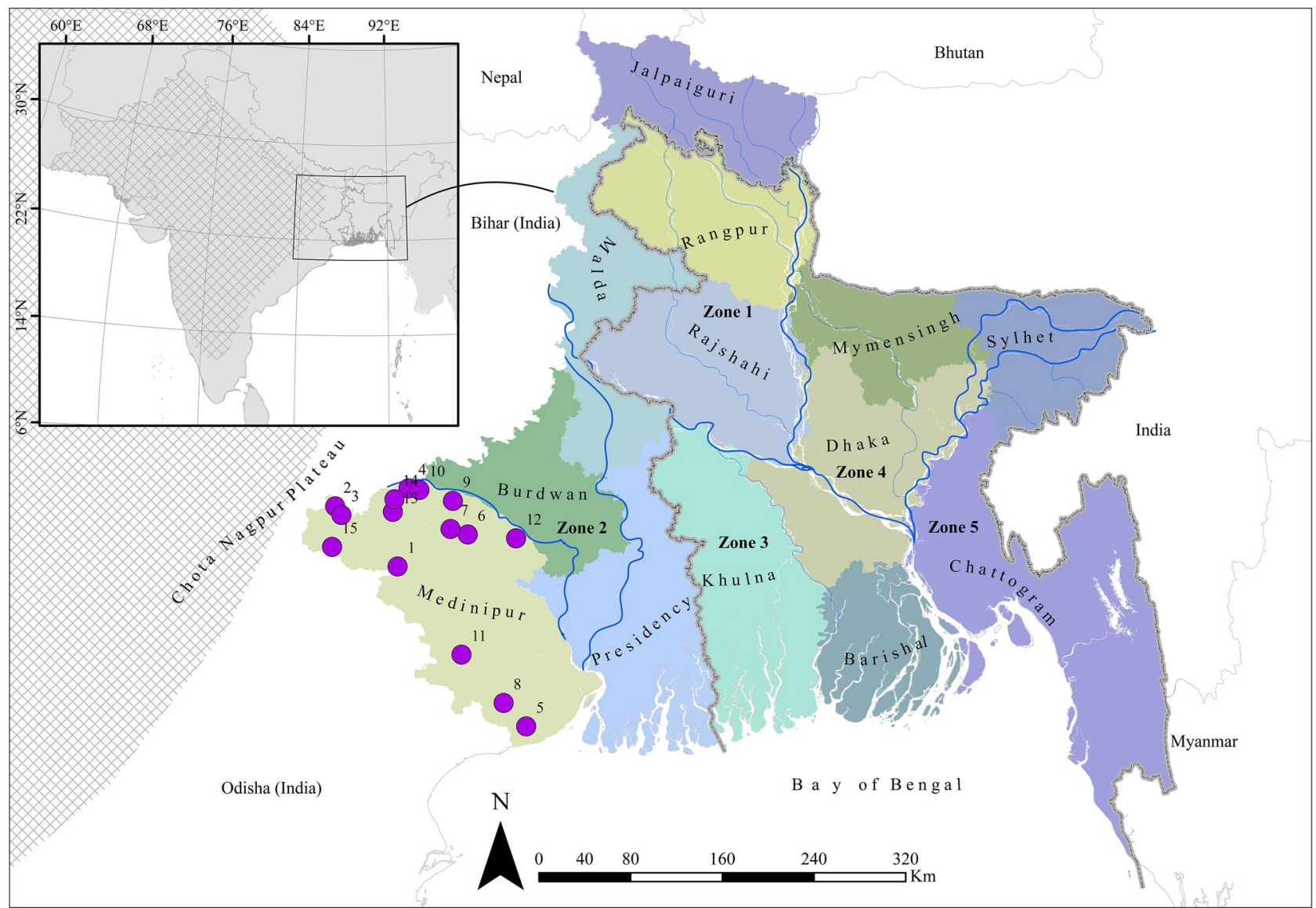

Fig. 2 Contemporary records of the striped hyena in Bengal with the delineation of divisions of West Bengal, India, and Bangladesh. The geographic position of Bengal in the Indian Subcontinent is shown in the inset. Black cross-hatched area denotes the current hyena range

published in multiple volumes between 1958 and 1990), and (v) Bangladesh District Gazetteer (an initiative by the Government of Bangladesh; published in multiple volumes between 1971 and 1990). Chronology and details of these compilations were obtained from Burton (1966), Scholberg (1970), and www.archive.org, and www.biodiversitylibrary. org. Gazetteers are considered to be comprehensive and reliable sources to trace past accounts (Laurini 2015; Acheson et al. 2017). Finally, we checked two journals that were operational since the eighteenth century: (i) The Journal of the Bombay Natural History Society (109 volumes; published between 1886 and 2012) and (ii) Journal of the Asiatic Society of Bengal (75 volumes; published between 1832 and 1936).

\section{Verification of occurrence records}

To verify any hyena-related event featured in the media and to avoid repeated entries, we followed a two-step approach. We considered a result pertinent only if the in the Indian Subcontinent (from AbiSaid and Dloniak 2015). Purple circles denote the contemporary hyena sighting locations. Numbers beside the circles are site codes and correspond to the observational briefs given in Table 2

location was within the present-day geopolitical boundary of West Bengal, India, or Bangladesh. Each report was used only if it had been published with an identifiable image of a hyena (dead or alive) or hyena spoor and/or included expert statements confirming species identification (e.g., from the West Bengal Forest Department personnel). All else was excluded from our analysis. For example, we did not consider the report of Sengupta (2020) as the identification of the conflict animal was uncertain. Similarly, we did not consider Mallick (2019) because it mentioned the presence of the striped hyena in West Bengal but did not specify any locality. We also excluded Maiti (2021) as, from the video provided with the report, we identified the animal as an Indian wolf (Canis lupus pallipes).

The data collected between 2010 and 2021 were classified under four themes: type, place, time, and source. Each theme was further classified under different considerations. Regarding the type of occurrence, the data were grouped into two categories: (i) human-hyena conflict and (ii) 
encounters in the wild. Human-hyena conflict corresponds to the retaliatory events induced by hyenas and/or by hyena attacks on humans or livestock as well as vehicle collisions. Any instance of hyena sightings in a wildlife survey or as an opportunistic event was defined as an encounter in the wild. The number of hyenas that appeared on each occasion, and damage, if any, caused by hyenas were also noted. We adopted definitions for these categorizations from Balme et al. (2014) and Akash et al. (2021a). The source, time (year, month, and date), and place (i.e., the type of habitat: forest, urban/peri-urban, or rural/agricultural; adopted from Acharya et al. 2016) of each event were also noted. When considering contemporary (2010-2021) occurrence events, we observed topographic traits of the occurrence location from Google Earth Imagery and noted pertinent district statistics compiled by RGCC (2011) and BBS (2011).

We have updated the historic and current easternmost distribution of the striped hyena to include the Bengal region. We procured the international boundary of India and Bangladesh from GADM.org. To refer to the status of forests of West Bengal, we consulted ISFR (2017); for Bangladesh, we followed IUCN Bangladesh (2015) and Khan (2018).

\section{Results and discussion}

In this first scientific report examining the easternmost distribution of the striped hyena, we have updated knowledge of the historic extent of the species and adjusted the current range map, pushing the distribution limit over $1000 \mathrm{~km}$ eastward from the current IUCN Red List range map (Fig. 1a, $\mathrm{b}$ and Tables 1 and 2; AbiSaid and Dloniak 2015). We have established West Bengal as being within the current range of the striped hyena in India. In addition, we present evidence that Bangladesh is a historical range country for the species. Asmat (2001), published in Bangla, is the only other known work that discussed hyena extinction in Bangladesh (Akash and Zakir 2020).

Our literature review compiled 14 historical works that noted striped hyena presence in Bengal (i.e., West Bengal, India, and Bangladesh; Table 1 and Fig. 1). The earliest of these anecdotes was in 1876 (Hunter 1876a-d). We also collated 15 contemporary records of the species that were verifiable, geographically explicit, and occurred in West Bengal between 2010 and 2021 (Table 2, Fig. 2, and Supplementary Fig. 1). From our work, it also appears that major rivers played a crucial role in both the expansion and extinction of hyena in Bengal (Fig. 1); the region lies on the largest delta in the world (IUCN Bangladesh 2015; ISRF 2017).

\section{Hyena in Bangladesh}

Within the historical evidence, we found four works (Hunter 1876c, d; Thomas 1885; Baker 1886) in which hyenas were reported to be present in areas that are now present-day Bangladesh (Site Code 4,5,6; Table 1; Fig. 1). The written accounts of the topographic features of these areas (Hunter 1876c, d; Thomas 1885; Baker 1886; Nishat et al. 2002; ISFR 2017; IUCN Bangladesh 2015) are comparable to the known habitat preferences of the striped hyena.

According to our zonal classification, two disconnected zones in Bangladesh (Zone 1 and Zone 5) were noted to have the species (Fig. 1). Zone 1 is characteristically drier, composed of grey terrace soils and open undulating knolls, and holds some of the oldest land formations from the Pleistocene era (Nishat et al. 2002; Figs. 1 and 2). Zone 1 once had a swath of wet deciduous forests covering almost half of the entire northern Bangladesh (Nishat et al. 2002; IUCN Bangladesh 2015). The historical topographic features of Zone 1 are similar to the habitat characteristics of the Chota Nagpur plateau, a neighboring region that currently has striped hyenas (Menon 2014). The Chota Nagpur plateau is drier, composed of red laterite soils, open scrublands, and dry deciduous forests (Kala and Dubey 2012). The eastern limit of the plateau abuts with the western boundary of historical Bengal. From Zone 1 of Bangladesh, the plateau is less than $100 \mathrm{~km}$ west in the shortest linear distance (Fig. 1). The southwestern part of Zone 5 contains coastal Bangladesh which, in the past, had stretches of grasslands along the coast (Hunter 1876d; Thomas 1885; Baker 1886; Nishat et al. 2002; IUCN Bangladesh 2015).

We reviewed the historical large mammal community that lived in Zones 1 and 5. Both of the zones had a similar assemblage that is known to prefer open forest systems, savanna, and grasslands (IUCN Bangladesh 2015; Khan 2018). For example, one of the last Asiatic cheetahs of Bengal (Acinonyx jubatus venaticus) was killed in Zone 1 in 1874 (Raoul 1893). Historically, the Indian wolf was extant in both zones at the same time (Akash et al. 2021b; Hunter 1876c, d; O’Malley 1914, 1923). Wolves disappeared from Bangladesh in the 1960s but still occur sympatrically with the striped hyena in the Chota Nagpur plateau (Kala and Dubey 2012; Sharma et al. 2019; Mukherjee et al. 2021).

The easternmost extent of the striped hyena in Bangladesh does not appear to have exceeded the Brahmaputra River (Fig. 1). However, in the south (Zone 5), the species likely crossed the Ganges-Brahmaputra-Meghna confluence based on three historical records of the striped hyena from coastal Bangladesh (Hunter 1876d; Thomas 1885; Baker 1886) (Site codes 5 and 6; Fig. 1 and Table 1). We consider these records authentic because of the abundance of scrubland-grassland mosaics during that period (suitable habitat for the species), the mentions of Indian wolves in a simultaneous manner (a large carnivore that shares several common habitat requirements and is sympatric with the striped hyena; Mukherjee et al. 2021), and the fact that the authors were experienced game hunters. The sighting from 
Table 1 Historical evidence collated on the presence of the striped hyena Hyaena hyaena in Bengal. Site code corresponds to the number provided in Fig. 1 and Supplementary Fig. 1

\begin{tabular}{|c|c|c|c|c|c|c|}
\hline Site code & Zone & Region/Country & $\begin{array}{l}\text { Name of the area } \\
\text { in historic } \\
\text { mentions }\end{array}$ & $\begin{array}{l}\text { Present-day division } \\
\text { comprising the area }\end{array}$ & Source & Quote verbatim/Remarks \\
\hline 1 & 2 & West Bengal & Midnapore & Medinipur & Hunter (1876a) & $\begin{array}{l}\text { "Tigers, leopards, hyaenas, bears, } \\
\text { buffaloes...frequent the jungle tracts } \\
\text { along the western boundary of the } \\
\text { district." }\end{array}$ \\
\hline 2 & 2 & West Bengal & Bankura & Medinipur & Hunter (1876b) & $\begin{array}{l}\text { "Tigers, leopards, small but fierce bears, } \\
\text { hyaenas, wolves, deer, and buffaloes... } \\
\text { frequent the jungle tracts along the } \\
\text { western boundary of the district, bears } \\
\text { and hyaenas being especially numerous." }\end{array}$ \\
\hline 3 & 1 & West Bengal & Maldah & Malda & Hunter (1876c) & $\begin{array}{l}\text { "The following is a list of the more } \\
\text { important wild animals: Tiger, leopard, } \\
\text { tiger cat, civet cat, mongoose, hyaena } \\
\text { (very rare), wolf (rare), jackal, and } \\
\text { occasionally, rhino (very rare), wild hog, } \\
\text { wild buffalo, large swamp deer, hog deer, } \\
\text { and spotted deer." }\end{array}$ \\
\hline 4 & 1 & Bangladesh & Rangpur & Rangpur & Hunter (1876c) & $\begin{array}{l}\text { "Foxes and jackals are numerous in every } \\
\text { part of Rangpur district, and hyaenas are } \\
\text { sometimes met with." }\end{array}$ \\
\hline 5 & 5 & Bangladesh & Noakhali & Chattogram & Hunter (1876d) & $\begin{array}{l}\text { "The following list of mammals found } \\
\text { in the district of Noakhali has been } \\
\text { furnished by collect (Mr R Porch, CS). } \\
\text { The scientific names are taken from } \\
\text { Dr Jerdon's Mammals of India: ...(12) } \\
\text { striped hyaena (Hyaena striata)...,(15) } \\
\text { Indian wolf (Canis pallipes)..." }\end{array}$ \\
\hline 6 & 5 & Bangladesh & Sitakundo & Chattogram & Thomas (1885) & $\begin{array}{l}\text { "Across the valley to the right rose an } \\
\text { almost perpendicular hill, its whole side } \\
\text { one tangle of long creepers and dense } \\
\text { undergrowth, save just at the centre, and } \\
\text { here a gap showed a pathway which led } \\
\text { across the face of the cliff. As I gazed at } \\
\text { this, a striped hyaena passed slowly along } \\
\text { a faintly-outlined track, quite } \\
\text { unconscious that he was observed." }\end{array}$ \\
\hline- & - & $\begin{array}{l}\text { Both Bangladesh } \\
\text { and West Bengal }\end{array}$ & - & - & Baker (1886) & $\begin{array}{l}\text { Baker (1886) mentioned the presence of } \\
\text { hyenas in Bengal multiple times, } \\
\text { however, did not specify the exact } \\
\text { localities }\end{array}$ \\
\hline 7 & 2 & West Bengal & Midnapore & Medinipur & Sclater (1891) & $\begin{array}{l}\text { One staffed specimen and a skull were } \\
\text { included in the catalogue of the } \\
\text { collection of the then Indian Museum, } \\
\text { Kolkata. These were procured from the } \\
\text { site mentioned }\end{array}$ \\
\hline 8 & 2 & West Bengal & Bankura & Medinipur & O'Malley (1908) & $\begin{array}{l}\text { "Among other carnivorous animals the } \\
\text { following are fairly common: hyaenas, } \\
\text { jackals, fox, civet cats, wild cats of } \\
\text { several species, as well as the ubiquitous } \\
\text { mongoose." }\end{array}$ \\
\hline 9 & 2 & West Bengal & Bardhaman & Burdwan & Peterson (1910) & $\begin{array}{l}\text { "Wolves have been known to carry off } \\
\text { children. Hyenas do not commit much } \\
\text { mischief as they content themselves with } \\
\text { carrion but they occasionally carry off } \\
\text { goats and sheep." }\end{array}$ \\
\hline 10 & 2 & West Bengal & Midnapore & Medinipur & O'Malley (1911) & $\begin{array}{l}\text { "Hyaenas are found in the jungles } \\
\text { bordering villages." }\end{array}$ \\
\hline
\end{tabular}


Table 1 (continued)

\begin{tabular}{|c|c|c|c|c|c|c|}
\hline Site code & Zone & Region/Country & $\begin{array}{l}\text { Name of the area } \\
\text { in historic } \\
\text { mentions }\end{array}$ & $\begin{array}{l}\text { Present-day division } \\
\text { comprising the area }\end{array}$ & Source & Quote verbatim/Remarks \\
\hline 11 & 1 & West Bengal & Dinajpur & Malda & Strong (1912) & $\begin{array}{l}\text { "Hyaenas are nowhere mentioned as } \\
\text { indigenous to the district, but in May } \\
1909 \text { an unmistakable hyena was seen in } \\
\text { the Bansihari thana (present-day Dakshin } \\
\text { Dinajpur)." }\end{array}$ \\
\hline 12 & 1 & West Bengal & West Dinajpur & Malda & Sengupta (1965) & $\begin{array}{l}\text { "Jackal, foxes, mongooses and hyaenas } \\
\text { are also found (present-day Paschim } \\
\text { Dinajpur)." }\end{array}$ \\
\hline 13 & 2 & West Bengal & Bankura & Medinipur & Banerji (1972) & $\begin{array}{l}\text { "The carrion-and-bone-eater striped hyena } \\
\text { is also found in the district but is strictly } \\
\text { nocturnal." }\end{array}$ \\
\hline 14 & 2 & West Bengal & Purulia & Medinipur & $\begin{array}{l}\text { Bhattacharya et al } \\
\text { (1985) }\end{array}$ & $\begin{array}{l}\text { "Hyenas are sometimes found in the dry } \\
\text { forests. It is a scavenger by nature, and } \\
\text { may carry away dogs and goats from } \\
\text { villages occasionally." }\end{array}$ \\
\hline
\end{tabular}

Thomas (1885) came from a hilly, semi-evergreen, streamfed forest-savanna mosaic (Zone 5; Site code 6; Figs. 1 and 2 and Table 1). The species is reported from similar habitats of East Africa (Castelló 2020). Similar instances have been noted for other species of hyenas. For example, the spotted hyena (Crocuta crocuta) has been observed in the tropical forests of Gabon by Bout et al. (2010). Immediately north of the possible historic range of the species in Zone 5 (Fig. 1) lie several settlements that predate the timeline of the British Indian Empire by thousands of years (Hunter 1876d; Thomas 1885; Baker 1886). Further east or south, the zone gains elevation and had dense mixed-evergreen forests in the nineteenth century (Baker 1886). Although Zone 5 may have offered habitats for the striped hyena in those periods, we did not come across any such suggestions.

If areas of Zone 5 were occupied by the striped hyena in historical times as we suggest, the presence of hyenas in Zone 3 (Central Bengal) can be deduced although no records were found. Immediately below the Ganges, in the 1900s, Zone 3 possessed three distinctive habitats: (i) complex grassland-sandbar mosaic near the banks of the Ganges and its tributaries, (ii) grassland-marshland mosaics (O'Malley 1914; 1923), and (iii) numerous estuarine rivers flowing through the southern tip of Zone 3 before emptying into the Bay of Bengal and forming the Sundarbans, the largest mangrove forest in the world (Khan 2018). However, hyenas never populated the mangroves, and the historic extent of the mangroves was more extensive. The grassland-sandbar mosaics, known to contain a rich wildlife including tiger (Panthera tigris), leopard (Panthera pardus), and buffalo (Bubalus arnee), is a possible historic dispersal route for striped hyenas to get into Zone 5 .

Similarly, we did not find any historic record of the species in Zone 4 . This region contains some of the oldest human settlements in Bengal; however, until the first half of the twentieth century, also held swaths of wet deciduous forests encompassing central Bangladesh and was rich in large vertebrates. These habitats may have been inhabited by hyenas. However, we consider that it would have been before the fifteenth century, if not prehistoric, which, in turn, is beyond the scope of this study. Combined with its secretive nature, and a less-coveted game species, the striped hyena was possibly overlooked in historic anecdotes that featured Zone 4 . In addition, the historic presence of hyenas in this region was certain to be influenced by an extreme nature event: the 1762 Arakan Earthquake impacted Bengal with an epicenter in Zone 5 and triggered a change in the main course of the Brahmaputra River (Fig. 1; Steckler et al. 2008). The course prior to the earthquake is known as the Old Brahmaputra River (Fig. 1; Sengupta 2011).

We found no works that discuss the extinction timeline of the striped hyena in Bangladesh. Hyenas in present-day Bangladesh were not mentioned in any work after the 1950s. The last anecdotes on wolves in the country were from the same period (Mitra 1957). Hyenas were likely extinct from the area south of the Ganges (Zones 3 and 5) first (before the 1920s), because these areas were subject to heavy land conversion and urbanization (Sengupta 2011). Currently, both zones hold some of the densest settlements in West Bengal and Bangladesh (RGCC 2011; BBS 2011). In Zone 1 , hyenas had disappeared at least a decade later than their timeline of possible extinction in Zone 3 or 5. For example, the latest mention is from Sengupta (1965), who stated the occasional presence of hyenas from northern West Bengal, India (Site code 12; Fig. 1), an area only $40 \mathrm{~km}$ away. We found one report, in Bangla, that considered the extinction of the striped hyena in Bangladesh (Asmat 2001), and it also compiled a few of the anecdotes presented here (for 
Table 2 Contemporary records collated on the presence of the striped hyena Hyaena hyaena in Bengal. Site code corresponds to the number provided on Fig. 1c and Supplementary Fig. 1c. Record sources correspond to those presented in Supplementary Fig. 2

\begin{tabular}{|c|c|c|c|c|c|c|c|c|c|}
\hline Site code & Zone & $\begin{array}{l}\text { Place of } \\
\text { occurrence } \\
\text { (Division) }\end{array}$ & $\begin{array}{l}\text { Place of } \\
\text { occurrence } \\
\text { (District) }\end{array}$ & Year & Month & $\begin{array}{l}\text { Type of } \\
\text { occurrence }\end{array}$ & $\begin{array}{l}\text { Hyena } \\
\text { killed?(y/n) }\end{array}$ & $\begin{array}{l}\text { Hyena } \\
\text { rescued? }\end{array}$ & Remarks \\
\hline 1 & 2 & Medinipur & Purulia & 2013 & December & $\begin{array}{l}\text { human-hyena } \\
\text { conflict }\end{array}$ & $\mathrm{y}$ & $\mathrm{n}$ & $\begin{array}{l}\text { One individual was killed by } \\
\text { poachers }\end{array}$ \\
\hline 2 & 2 & Medinipur & Purulia & 2014 & - & $\begin{array}{l}\text { human-hyena } \\
\text { conflict }\end{array}$ & $\mathrm{n}$ & $\mathrm{y}$ & $\begin{array}{l}\text { One individual was ventured } \\
\text { into locality }\end{array}$ \\
\hline 3 & 2 & Medinipur & Purulia & 2015 & September & $\begin{array}{l}\text { human-hyena } \\
\text { conflict }\end{array}$ & $\mathrm{y}$ & $\mathrm{n}$ & $\begin{array}{l}\text { One individual was crushed by } \\
\text { train. The report also } \\
\text { mentioned about five more } \\
\text { train accidents that involved } \\
\text { hyena death and occurred } \\
\text { between 2014-2015 }\end{array}$ \\
\hline 4 & 2 & Medinipur & Purulia & 2015 & September & $\begin{array}{l}\text { human-hyena } \\
\text { conflict }\end{array}$ & $\mathrm{y}$ & $\mathrm{n}$ & $\begin{array}{l}\text { One individual was crushed } \\
\text { by train }\end{array}$ \\
\hline 5 & 2 & Medinipur & $\begin{array}{l}\text { Purba } \\
\text { Medinipur }\end{array}$ & 2016 & February & $\begin{array}{l}\text { human-hyena } \\
\text { conflict }\end{array}$ & $\mathrm{y}$ & $\mathrm{n}$ & $\begin{array}{l}\text { One individual was ventured } \\
\text { into locality, killed by vil- } \\
\text { lagers }\end{array}$ \\
\hline 6 & 2 & Medinipur & Bankura & 2016 & November & $\begin{array}{l}\text { human-hyena } \\
\text { conflict }\end{array}$ & $\mathrm{y}$ & $\mathrm{n}$ & $\begin{array}{l}\text { One individual was found dead } \\
\text { nearby locality }\end{array}$ \\
\hline 7 & 2 & Medinipur & Bankura & 2016 & December & $\begin{array}{l}\text { human-hyena } \\
\text { conflict }\end{array}$ & $\mathrm{y}$ & $\mathrm{n}$ & $\begin{array}{l}\text { One individual was found dead } \\
\text { nearby locality }\end{array}$ \\
\hline 8 & 2 & Medinipur & $\begin{array}{l}\text { Paschim } \\
\text { Medinipur }\end{array}$ & 2018 & November & $\begin{array}{l}\text { human-hyena } \\
\text { conflict }\end{array}$ & $\mathrm{n}$ & $\mathrm{y}$ & $\begin{array}{l}\text { One individual was ventured } \\
\text { into locality, rescued by vil- } \\
\text { lagers }\end{array}$ \\
\hline 9 & 2 & Medinipur & Bankura & 2018 & May & $\begin{array}{l}\text { human-hyena } \\
\text { conflict }\end{array}$ & $\mathrm{y}$ & $\mathrm{n}$ & $\begin{array}{l}\text { One individual was found dead } \\
\text { nearby locality }\end{array}$ \\
\hline 10 & 2 & Medinipur & Purulia & 2018 & - & $\begin{array}{l}\text { encounter in } \\
\text { the wild }\end{array}$ & $\mathrm{n}$ & $\mathrm{n}$ & $\begin{array}{l}\text { Only peer-reviewed study that } \\
\text { stated presence of the species } \\
\text { in West Bengal. Exact date/ } \\
\text { month of the sighting event } \\
\text { could not be retrieved } \\
\text { According to Chattopahyay } \\
\text { et al. (2018), "Striped Hyaena } \\
\text { was observed only once } \\
\text { duringthe present study but } \\
\text { reports by local villagers } \\
\text { suggest that they were spotted } \\
\text { at least five times during the } \\
\text { present study duration (two } \\
\text { years)." }\end{array}$ \\
\hline 11 & 2 & Medinipur & Jhargram & 2019 & March & $\begin{array}{l}\text { human-hyena } \\
\text { conflict }\end{array}$ & $\mathrm{n}$ & $\mathrm{n}$ & $\begin{array}{l}\text { One individual attacked a goat } \\
\text { and injured the owner of the } \\
\text { goat }\end{array}$ \\
\hline 12 & 2 & Medinipur & Bankura & 2019 & July & $\begin{array}{l}\text { human-hyena } \\
\text { conflict }\end{array}$ & $\mathrm{y}$ & $\mathrm{n}$ & $\begin{array}{l}\text { One individual found dead } \\
\text { nearby locality }\end{array}$ \\
\hline 13 & 2 & Medinipur & Purulia & 2020 & July & $\begin{array}{l}\text { human-hyena } \\
\text { conflict }\end{array}$ & $\mathrm{y}$ & $\mathrm{n}$ & $\begin{array}{l}\text { One individual was killed, } \\
\text { allegedly by poachers }\end{array}$ \\
\hline 14 & 2 & Medinipur & Purulia & 2020 & December & $\begin{array}{l}\text { human-hyena } \\
\text { conflict }\end{array}$ & $\mathrm{n}$ & $\mathrm{y}$ & $\begin{array}{l}\text { One individual rescued from } \\
\text { paddy field }\end{array}$ \\
\hline 15 & 2 & Medinipur & Purulia & 2021 & January & $\begin{array}{l}\text { encounter in } \\
\text { the wild }\end{array}$ & $\mathrm{n}$ & $\mathrm{n}$ & $\begin{array}{l}\text { One individual was sighted } \\
\text { from car. It is very likely the } \\
\text { first live footage in the region }\end{array}$ \\
\hline
\end{tabular}


example, Hunter 1876c, d ). Our observations corroborate with Asmat (2001) and ongoing research by the Hyaena Distribution Mapping Project (authors' unpublished data).

Based on the historical records and the similarity of the historical topographic and ecological features of Bengal and its large mammal community, we conjecture that the striped hyena was once present across northern Bangladesh, and possibly also in riverine and coastal grasslands of southcentral Bangladesh. The species likely went extinct in the country in the 1960s and was one of the first large carnivores to go extinct from the country.

\section{Hyena in West Bengal, India}

Zone 1 and Zone 2 of Bengal, i.e., present-day West Bengal nearly in its entirety, had the striped hyena in historical times. We collated 12 historical accounts that described the presence of hyenas from what is now West Bengal (Table 1 and Fig. 1). In northern West Bengal (Zone 1), the Teesta tributaries of the Brahmaputra River marked the northernmost extent of the historical hyena presence. No description beyond this geographic barrier mentioned hyenas in any period. West Bengal lost hyenas in the northern part, i.e., north of the Ganges, first. After Sengupta (1965), we found no mentions of hyenas beyond this limit. We did not consider the northern half of Zone 1 as a historic range of hyenas. This half of Zone 1, in the time of the British Indian Empire, was primarily forest but was extensively cleared to make room for tea-gardens. It still contains some of the oldest tea-gardens in the subcontinent. The region was also impacted by the 1762 Arakan Earthquake. In 1787, a massive and prolonged flooding period changed the tributaries of the Teesta River and pushed them eastward (Fig. 1; Rahman et al. 2011). Our deduction on this region is based on these considerations, which ought to be unfavorable for the hyenas.

The southern half of West Bengal (Zone 2) had the striped hyena in most of its areas (Site codes 1, 2, 7, 8, 9, 10, 12, and 14; Fig. 1). Sclater (1891) noted stuffed specimens and skulls of hyenas in the Indian Museum, which were sourced from Zone 2. However, the eastern part, the Presidency Division, had no mentions about the striped hyena as it holds the Sundarbans (never inhabited by the hyena) and the areas that had been transformed heavily since the 1900s (Sengupta 2011). The western part of Zone 2 is the eastern extremities of the Chota Nagpur plateau, which has open savanna systems, formed on dry, lateritic, and red soil highlands (RGCC 2011); further west, the zone continues into the Indian states of Odisha and Jharkhand (Fig. 2).

We noted 15 contemporary records of the striped hyena from West Bengal that occurred between 2010 and 2021 (Table 2, Fig. 2, and Supplementary Fig. 1). All but two surfaced as media records. The two non-media records were also the only reported wild encounters with hyenas in West
Bengal. The remaining 13 were outcomes of human-hyena conflict. On six occasions, single individuals were found dead in the vicinity of nearby villages. These incidents were allegedly due to poachers (Site codes 1, 6, 7, 9, 12, and 13; Table 2, Fig. 2, and Supplementary Fig. 1). On two reported occasions, hyenas were killed by trains (Site codes 3 and 4; Table 2, Fig. 2, and Supplementary Fig. 1). Death of hyenas by train in the state was reported as a common phenomenon (Site code 3; Table 2, Fig. 2, and Supplementary Fig. 1). On another four occasions, one individual on each occasion strayed into villages (Site codes 2, 5, 8, and 14; Table 2, Fig. 2, and Supplementary Fig. 1). All were rescued except on one occasion where the animal was killed. One incident reported an attempted hunt on a domestic goat. Chattopadhyay et al. (2018) is the only peer-reviewed work we found that noted the species' presence in West Bengal. In total, these reports between 2010 and 2021 noted about 25 hyena sightings including 9 deaths. All of these incidents occurred south of the Damodar River (Fig. 2). From our review, we found that the western part of West Bengal (Midnapore Division) is the only area in Bengal that still has the striped hyena. Although the recent records may suggest an increase of range of the striped hyena by approximately $1,000 \mathrm{~km}^{2}$ eastward (Fig. 2), they are plausibly relict sub-populations of striped hyenas that were not included by Mills and Hofer (1998), likely because data were not received during their survey process and therefore not included in the map. The region lying south of the Damodar River is also the last refuge of the Indian wolf in Bengal (Sharma et al. 2019).

\section{Conclusion}

Our findings contribute new knowledge about the striped hyena's current and historical distribution and to its conservation. Given the habitat and topographic features of Bengal, the natural disasters that occurred there, and the historical evidence we found, the extent of hyenas included present-day Bangladesh. It would therefore be prudent to conduct a study from a paleontological perspective. Since historic times, the striped hyena has been a species of human neglect. According to Thomas (1885) and Baker (1886), the species was the least prized (even less so than wolves) among hunters. Hyenas were thus absent in most of the famous historical anecdotes on pig-sticking practices and the game mammals of the Indian subcontinent. The striped hyena population receded gradually, likely through a combination of persecution, habitat loss, and prey loss exacerbated by game hunting, facing a silent extinction throughout Bangladesh and most of West Bengal. We found no studies on hyenas in Bengal in either of the primary natural history journals we considered. Hyenas are still facing the same treatment and lack of 
attention. This situation has only changed in the past year, as according to Nandi (2021), the Zoological Survey of India recently initiated a systematic survey on the striped hyena in West Bengal.

Our work also suggests additional methods which can be applied to delineate the historical extent of the striped hyena and to similar lesser-known species. For instance, the extent of the striped hyena in the remaining part of its Asian range could be further elucidated using similar methods (in particular in Turkey and Central Asia). Without an accurate understanding of a species' historical distribution and the ecological conditions in which it was found, scientific interpretation of fundamental and realized niches, the application of appropriate management measures, and analysis of factors affecting fitness can be biased. For example, according to Han et al. (2019), a previous lack of historical context for the giant panda's (Ailuropoda melanoleuca) distribution and behavior was suggested to have hamstrung conservation efforts until recently due to a poor understanding of what the species needs to persist. Similarly, a review on the European bison (Bison bonasus) historical population dynamics helped to identify major threats that benefitted the current management of the species (Samojlik et al. 2019). Thus, studies such as ours which identify and interpret local extinctions and historical distributions can inform presentday management and conservation. We contend that it is crucial to examine historical and local knowledge to gain a complete understanding of basic species ecology and to implement evidence-based conservation policies, planning, and actions. Importantly, without this review, we would have assumed that the recent records in West Bengal would have implied a range extension of nearly $1,000 \mathrm{~km}$ east of the existing distribution limits, as opposed to recognizing it as a relict population deserving of conservation attention.

Supplementary information The online version contains supplementary material available at https://doi.org/10.1007/s10344-021-01552-9.

Acknowledgements We are thankful to Sanjay Gubbi for linking us to the archives of the Journal of Bombay Natural History Society. Thanks are also due to Onu Tareq and Amarta Galib Chowdhury for providing information about Asmat (2001) and Thomas (1885). Finally, we thank two anonymous reviewers for providing helpful comments on the manuscript.

Author contribution $\mathrm{AD}, \mathrm{AJ}$, and SMD conceptualized the idea. MA designed the methodology, compiled data, and prepared the maps. AD and MA prepared the manuscript. All authors reviewed and approved the manuscript.

Funding Open Access funding enabled and organized by Projekt DEAL. This research was a self-funded endeavor.

Availability of data and material Not applicable.

Code availability Not applicable.

\section{Declarations}

Ethics approval Not applicable.

Consent to participate Not applicable.

Consent for publication Not applicable.

Competing interests The authors declare no competing interests.

Open Access This article is licensed under a Creative Commons Attribution 4.0 International License, which permits use, sharing, adaptation, distribution and reproduction in any medium or format, as long as you give appropriate credit to the original author(s) and the source, provide a link to the Creative Commons licence, and indicate if changes were made. The images or other third party material in this article are included in the article's Creative Commons licence, unless indicated otherwise in a credit line to the material. If material is not included in the article's Creative Commons licence and your intended use is not permitted by statutory regulation or exceeds the permitted use, you will need to obtain permission directly from the copyright holder. To view a copy of this licence, visit http://creativecommons.org/licenses/by/4.0/.

\section{References}

AbiSaid M, Dloniak SM (2015) "Hyaena hyaena". IUCN Red List of Threatened Species. 2015: e.T10274A45195080. Accessed 26 Mar 2021

Acharya KP, Paudel PK, Neupane PR, Köhl M (2016) Human-wildlife conflicts in Nepal: patterns of human fatalities and injuries caused by large mammals. PLoS One 11:e0161717. https://doi.org/10. 1371/journal.pone.0161717

Acheson E, De Sabbata S, Purves RS (2017) A quantitative analysis of global gazetteers: patterns of coverage for common feature types. Comput Environ Urban Syst 64:309-320. https://doi.org/ 10.1016/j.compenvurbsys.2017.03.007

Ahmed ATA, Kabir SMH, Ahmad M, Hasan MA, Khondker M (eds) (2009) Encyclopedia of Flora and Fauna of Bangladesh, vol 27. Asiatic Society of Bangladesh, Dhaka, Mammals

Akash M, Trageser S, Zakir T, Rahman SC, Mila FTZK, Ghose A (2021a) Detecting the spots: a review on leopard occurrences in Bangladesh. CatNews. Accepted

Akash M, Chowdhury UF, Reza RN, Howlader DC, Islam MR, Khan $\mathrm{H}$ (2021b) On the reappearance of the Indian grey wolf in Bangladesh after 70 years: what do we know? Mamm Biol 101(2):163171. https://doi.org/10.1007/s42991-020-00064-4

Akash M, Zakir T (2020) Appraising carnivore (Mammalia: Carnivora) studies in Bangladesh from 1971 to 2019 bibliographic retrieves: trends, biases, and opportunities. J Threat Taxa 12(15):1710517120. https://doi.org/10.11609/jott.6486.12.15.17105-17120

Asmat GSM (2001) Bangladesher Bilupta Bannaprani (In Bangla)/ extinct animals of Bangladesh. Bangla Academy, Dhaka

Athreya V, Srivathsa A, Puri M, Karanth KK, Kumar NS, Karanth KU (2015) Spotted in the news: using media reports to examine leopard distribution, depredation, and management practices outside protected areas in Southern India. PLoS One 10:e0142647. https://doi.org/10.1371/journal.pone.0142647

Baker EB (1886) Sport in Bengal: how, when, and where to seek it. Smith \& Co., London

Balme GA, Lindsey PA, Swanepoel LH, Hunter LT (2014) Failure of research to address the range-wide conservation needs of large carnivores: leopards in South Africa as a case study. Conserv Lett 7(1):3-11. https://doi.org/10.1111/conl.12028 
Banerji AK (1972) Gazetteer of India: West Bengal District Gazetteers, Bankura. Government of West Bengal, Kolkata, pp 45-46

BBS (2011) District Statistics Bangladesh Bureau of Statistics, Government of Peoples Republicof Bangladesh. Available: http://www. bbs.gov.bd/. Accessed 25 Sept 2020

Bhandari S, Morley C, Aryal A, and Shrestha UB (2020) The diet of the striped hyena in Nepal's lowland regions. Ecol and Evol 10(15):7953-62. https://doi.org/10.1002/ece3.6223

Bhattacharya BK, Ray P, Chokroborty BR, Sengupta KS, Mukherji S, Sen NN and Maity T (1985) Gazetteer of India: West Bengal District Gazetteers, Puruliya. Government of West Bengal, Kolkata, pp 60-61

Bout N, Born C, Spohr C (2010) Evidence that the spotted hyena is present in the rainforest-savannah mosaic of south-east Gabon. Mammal Biol 75(2):175-179. https://doi.org/10.1016/j.mambio. 2009.03.005

Burton J (1966) Jatindra Chandra Sengupta: West Dinājpur. (Gazetteer of India. West Bengal District Gazetteers.) xv, 259 pp. Calcutta:[Government of West Bengal], 1965. Rs. 15. Bull Sch Orient Afr Stud 29(2):403-404

Castelló JR (2020) Felids and Hyenas of the world: wildcats, panthers, lynx, pumas, ocelots, caracals, and relatives. Princeton University Press, New Jersey

Chattopadhyay S, Dey S, Roy US (2018) On the diversity of the vertebrate fauna (excluding fishes) of Panchet Hill (Garh Panchkot), Purulia, West Bengal, India. J Threat Taxa 10(15):12979-12985. https://doi.org/10.11609/jott.3555.10.15.13017-13019

Derouiche L, Bounaceur F, Benamor N, Hadjloum M, BenameurHasnaoui H, Ounas H, Irzagh A, Boualem A, Belmoures R, Djeghim C, Aulagnier S (2020) Distribution and status of the striped hyena Hyaena hyaena (Linnaeus, 1758) (Mammalia, Hyaenidae) in Algeria. Mammalia 84(5):421-428. https://doi.org/10. 1515/mammalia-2019-0085

Han H, Wei W, Hu Y, Nie Y, Ji X, Yan LI, Wei F (2019) Diet evolution and habitat contraction of giant pandas via stable isotope analysis. Curr Biol 29(4):664-669. https://doi.org/10.1016/j.cub. 2018.12.051

Hary A (2021) The 10 best Bengali newspapers in India. MyBangla24. com. https://mybangla24.com/bengali-newspapers. Accessed 18 Apr 2021

Hunter L, Barrett P (2018) Field guide to carnivores of the world. Bloomsbury Wildlife, New York

Hunter WW (1876a) A Statistical Account of Bengal, Vol 3. Trübner \& Co., London, Midnapore and Hooghli, p 39

Hunter WW (1876b) A Statistical Account of Bengal, Vol. 4, Bardhman, Bankura, Birbhum. Trübner \& Co., London, pp 212-213

Hunter WW (1876c) A Statistical Account of Bengal, Vol. 7, Malda, Rangpur, Dinajpur. Trübner \& Co., London, pp 34, 199

Hunter WW (1876d) A Statistical Account of Bengal, Vol. 6, Chittagong Hill Tracts, Chittagong, Noakhali, Tipperah and Hill Tipperah. Trübner \& Co., London, pp 258-259

ISFR (2017) Indian State Forest Report (Assam, Mizoram, Meghalaya, Tripura, West Bengal). Forest Survey of India, Ministry of Environment, Forest and Climate Change, Government of India. https://www.fsi.nic.in/forest-report-2017. Accessed 25 Sept 2020

IUCN Bangladesh (2000) Red list of threatened animals of Bangladesh. IUCN International Union for Conservation of Nature, Bangladesh Country Office, Dhaka

IUCN Bangladesh (2015) Red list of Bangladesh Volume 2: Mammals. IUCN, International Union for Conservation of Nature, Bangladesh Country Office, Dhaka

Jacobson AP, Gerngross P, Lemeris Jr JR, Schoonover RF, Anco C, Breitenmoser-Würsten C, Durant SM, Farhadinia MS, Henschel P, Kamler JF, Laguardia A (2016) Leopard (Panthera pardus) status, distribution, and the research efforts across its range. PeerJ 4:e1974. https://doi.org/10.7717/peerj.1974

Kala CP, Dubey Y (2012) Anthropogenic disturbances and status of forest and wildlife in the dry deciduous forests of Chhattisgarh state in India. J for Res 23(1):45-52. https://doi.org/10.1007/ s11676-012-0116-0

Khan MAR (2015) Wildlife of Bangladesh: checklist and guide. Chayabithi, Dhaka

Khan MMH (2018) Photographic guide to the wildlife of Bangladesh. Arannayk Foundation, Dhaka

Laurini R (2015) Geographic ontologies, gazetteers and multilingualism. Future Internet 7(1):1-23. https://doi.org/10.3390/fi7010001

Lozano J, Olszańska A, Morales-Reyes Z, Castro AA, Malo AF, Moleon M, Sánchez-Zapata JA, Cortés-Avizanda A, von Wehrden H, Dorresteijn I, Kansky R (2019) Human-carnivore relations: a systematic review. Biol Conserv 237:480-492. https://doi.org/10. 1016/j.biocon.2019.07.002

Maiti R (2021) হায়নার আকরমণढ জখম ১ বযকর্ত (in Bangla) https:// indianprimetime.in/one-person-was-injured-in-the-hyena-attack/. Accessed 20 Mar 2021

Mallick JK (2019) An updated checklist of the mammals of West Bengal. J New Biol Rep 8(2):34-124

Menon V (2014) Indian mammals: a field guide. Hachette Book Publishing, Haryana

Mills G, Hofer H (1998) Hyaenas: status survey and conservation action plan. IUCN, SSC Hyaena Specialist Group, Gland, Switzerland

Mitra SN (1957) Banglar shikar prani (in Bangla). Press, India, West Bengal Govt

Mukherjee T, Chongder I, Ghosh S, Singh A, Dutta R, Joshi BD, ... and Chandra K. (2021). Indian Grey Wolf and Striped Hyaena sharing from the same bowl: high niche overlap between top predators in a human-dominated landscape. Global Ecology and Conservation, $\mathrm{e} 01682$.

Nandi S (2021) ZSI survey finds striped Hyena, Grey wolf population doing well in South Bengal forests. http://www.millenniumpost. in/kolkata/zsi-survey-finds-striped-hyena-grey-wolf-populationdoing-well-in-south-bengal-forests-428890. Accessed 26 Mar 2021

Nishat A, Huq SM, Imamul B, Shuvashish P, Reza AHMA, Moniruzzaman ASK (eds) (2002) Bio-ecological zones of Bangladesh. IUCN. International Union Conservation for Nature, Bangladesh Country Office, Dhaka, p 141

O'Malley LSS (1908) Bengal District Gazetteers, Bankura. The Bengal Secretariat Book Depot., Kolkata, p 16

O'Malley LSS (1911) Bengal District Gazetteers, Midnapore. The Bengal Secretariat Book Depot., Kolkata, p 19-20

O'Malley LSS (1914) Bengal District Gazetteers, Murshidabad. The Bengal Secretariat Book Depot., Kolkata

O'Malley LSS (1923) Bengal District Gazetteers, Pabna. The Bengal Secretariat Book Depot., Kolkata

Peterson JCK (1910) Bengal District Gazetteers, Burdwan. The Bengal Secretariat Book Depot., Kolkata, p 19

Pullin AS, Stewart GB (2006) Guidelines for systematic review in conservation and environmental management. Conserv Biol 20(6):16471656. https://doi.org/10.1111/j.1523-1739.2006.00485.x

RGCC (2011) Census Statistics. RGCC, Registrar General and Census Commissioner, Government of the Republic of India. http://www. census2011.co.in/district.php ISRF 2017. Accessed 25 Sept 2020

Raoul (1893) Reminiscences of twenty years' pigsticking in Bengal. Spink Thacker and Co., Kolkata, p 153

Rahman MM, Arya DS, Goel NK, Dhamy AP (2011) Design flow and stage computations in the Teesta River, Bangladesh, using frequency analysis and MIKE 11 modeling. J Hydrol Eng 16(2):176-186. https://doi.org/10.1061/(ASCE)HE.1943-5584. 0000299 
Samojlik T, Fedotova A, Borowik T, Kowalczyk R (2019) Historical data on European bison management in Białowieża Primeval Forest can contribute to a better contemporary conservation of the species. Mammal Res 64(4):543-557

Scholberg H (1970) The District Gazetteers of British India: a bibliography. Inter Documentation Company, Zug

Sclater WL (1891) Catalogue of Mammalia in the Indian Museum. Vol II. The Trustees of the Indian Museum, Kolkata, pp 258-259

Sengupta JC (1965) Gazetteer of India: West Bengal District Gazetteers, West Dinajpur. Government of West Bengal, Kolkata, p $13-14$

Sengupta NK (2011) Land of two rivers: a history of Bengal from the Mahabharata to Mujib. Penguin Books, London

Sengupta S (2020) খতেদদ পুলশি সুপাররে অফসিরে সামনইই অজানা বন্যপরাণীর আনাগণেননা! পায়রে ছাপ ঘরিট তীবর আতঙ্ক (in Bangla)/Panic grips at Jhargram city to see footprints of unknown animal (in English). https://www.sangbadpratidin.in/bengal/panicgrips-at-jhargram-city-to-see-footprints-of-unknown-animal/. Accessed 20 Mar 2021

Steckler MS, Akhter SH, Seeber L (2008) Collision of the GangesBrahmaputra Delta with the Burma Arc: implications for earthquake hazard. EPSL 273(3-4):367-378. https://doi.org/10.1016/j. eps1.2008.07.009
Sharma LK, Mukherjee T, Saren PC, Chandra K (2019) Identifying suitable habitat and corridors for Indian Grey Wolf (Canis lupus pallipes) in Chotta Nagpur Plateau and Lower Gangetic Planes: a species with differential management needs. PLoS One 14(4):e0215019. https://doi.org/10.1371/journal.pone.0215019

Strong FW (1912) Bengal District Gazetteers, Bankura. The Bengal Secretariat Book Depot., Kolkata, pp 10-11

Thomas HL (1885) A fly on the wheel or how I helped to govern India. Allen \& Co., London, p 200

Tichon J, Rotem G, Ward P (2016) Estimating abundance of striped hyenas (Hyaena hyaena) in the Negev Desert of Israel using camera traps and closed capture-recapture models. Eur J Wildl Res 63(1):1-3. https://doi.org/10.1007/s10344-016-1069-y

Tichon J, Gilchrist JS, Rotem G, Ward P, Spiegel O (2020) Social interactions in striped hyena inferred from camera trap data: is it more social than previously thought? Curr Zool 66(4):345-353

Wagner AP (2006) Behavioral ecology of the striped hyena (Hyaena hyaena). Dissertation, Montana State University

Watts HE, Holekamp KE (2007) Hyena societies. Curr Biol 17(16):657-660

Publisher's Note Springer Nature remains neutral with regard to jurisdictional claims in published maps and institutional affiliations. 